\title{
Digitization of the agricultural crop industry as a factor for business growth
}

\author{
Dmitry Frolov ${ }^{1}$, Milana Shevchenko ${ }^{2}$, and Natella Kosenko ${ }^{3 *}$ \\ ${ }^{1}$ Management Departament the Food Markets and Services, Administration of Mr., 26, Sovetskaja, \\ 354000, Sochi, Russia \\ ${ }^{2}$ Private educational institution of higher education «Moscow Witte University», 78, Nefedova, \\ 344018, Rostov-on-Don, Russia \\ ${ }^{3}$ Don State Technical University, 1, Gagarina sq., 344003, Rostov-on-Don, Russia
}

\begin{abstract}
The production costs of agricultural enterprises of 43 rural areas in the South of Russia, which systematically cultivate the same types of crops: winter and spring grains, pulse crops, maize, sunflower, potatoes and open field vegetables, has been investigated. Mathematical tools for cost forecasting and long-term planning of production of the most competitive species for profitable sales on the world (grain) and domestic product markets are shown.
\end{abstract}

\section{Introduction}

The main strategy of the agricultural producers is to minimize the unit production cost. Purchase prices for crop products should be included in the enterprise's operating programme, not exceeding the loss of $10 \%$ of the price, updating early mature cultivars (less energy inputs) and sales markets with a low entry threshold, individual outlets.

In this regard, it is particularly important to have calculations of the predicted production cost of a unit of crop production.

To this end, agricultural enterprises of 43 rural areas in the South of Russia, which systematically cultivate the same crop varieties: winter and spring grains, pulses, maize, sunflower, potatoes and open field vegetables, were studied.

\section{Methods and materials}

The subject area of the research is the integration of economic and mathematical technologies into the calculation of production costs, application of mathematical tools for forecasting and long-term planning of production of the most competitive types of goods for profitable sales on the world (grain) and domestic food markets.

Reports of high grain yields in various regions of the world coincided in time with the world economic crisis [1-5]. Pressure on the exchange rate on agrarian stock exchanges increased, and as a result, there was a currency depreciation in the oil market due to the prices of diesel fuel and gasoline, which further affected the price of oilseeds and maize [69]. Trading houses refused credit guarantees for fertilizer ships. The cost of imported fertilizers has increased for Russians - they reduced the amount of purchases, hence the yield of crop production decreased. Production costs in crop production have increased not 
only in Russia, but also in the world [10-15]. As a result, production costs increased by $700-1000$ rubles/ton in the light of the rising cost of seeds, fertilizers and energy. It became impossible to produce wheat for 4500 rubles/ton (2018 price level) at full cost worldwide. Price is determined by supply and demand. For example, it is up to the grain producer to decide whether to cultivate grain in the current season (many producers switch to berries and fruits). It depends on the current contribution to covering the cost of seeds, fertilizers, fuel and energy resources. The cost of labour of a rural worker is not considered, although it makes up to about $12 \%$ of the cost of the finished product due to the small proportion of mechanized labour. However, low labour costs of agricultural producers are not accompanied by declining yields for a variety of reasons, including natural industriousness of the villagers and love for the land.

In 2020, agricultural producers, possessing knowledge of inference logic based on economic and mathematical tools: 1) increased sown area; 2) increased crop yield; 3) increased the volume of investments in the purchase of new equipment, mainly Russian, by about 60 billion rubles. Rostselmash this year increased the sales of combine harvesters of various purposes and tractors by $35 \%$. Strategically important enterprises did not cease operations of self-propelled machinery production, product-oriented farming systems high-tech and combined tools due to the pandemic. Export-import chains were temporarily interrupted. The demand for Kamaz vehicles has increased among farmers. Some farms started to sell in trade-in foreign-made equipment and to buy KAMAZ vehicles. The Ministry of Industrial Development grant plays a key role. Under this programme, by the end of September 2020, the State reimburses the buyer of domestic equipment in the amount of $12.5 \%$ of its value, including leasing. Demand for foreign agricultural machinery has declined. LLC "Oil Extraction Plant Yug Rusi" operates on domestic equipment, as well as the Svetly Group of Companies and the Upral-Don Holding. Although there are agricultural firms such as "Celina", CJSC "SKVO", working on imported equipment [1620].

Not least important is the fact that there has been an increase in depreciation due to the abrupt rise in prices for agricultural machinery. For many agricultural producers, the costs do not pay off. Under the socialist method of crop production, the cost recovery was not even calculated, since all the self-propelled machinery was transferred by the State to the collective farms for free, and the crop was sent to the shops at a price far below cost. The principle of reducing labour costs by introducing the most productive agricultural machinery, repairable and durable, remained invariably fundamental (the service life of combine harvesters manufactured by KZ Rostselmash LLC exceeded 35 years of seasonal work).

Direct costs (for a particular type of crop) and indirect costs, simultaneously used for several types of crop (repair of machinery, general factory expenses, warehousing, silo or handheld storage, etc.) can be distinguished according to the way in which crop production is priced. Indirect costs can only be estimated at the end of the agricultural year.

However, each crop enterprise must annually assess its actuary (the ability to pay its bills) by drawing up a detailed liquidity plan for each year, reducing costs through forward transactions and futures resale of the contracts themselves, other stock exchanges [21-25]. Due to the seasonality of income, agricultural organizations find it difficult to raise capital on their own bank account.

During harvesting grain harvests (winter and spring), energy costs are often reduced by raising the header.

But this is reflected in the loss of underutilized resource in Russia: straw, empty glume, and tendril. Neither domestic nor foreign combine harvesters harvest, sometimes in vain, they heap straw. However, straw, empty glume, and tendril are an alternative nutritious product. There is a need for the design development of combine harvesters, the creation of 
mills for grinding and converting these by-products into food flour, not only for animals, but also for people. This can be done by scientists from the universities of Zernograd in the Rostov region, who have successfully solved the problem of regenerating used industrial, transformer, and then motor oils. The above-mentioned scientists have sufficient knowledge on the processing of landfills that pollute farmland and crop products, the extraction of methane from the depths of garbage heaps, and the benefits of treatment facilities.

Efficient labour organization, efficient and reliable equipment, knowledge of managerial dispatching, cost-effective connection of grain harvesting equipment with transport for unloading bunkers are decisive prerequisites for reducing crop production costs.

\section{Results and discussing}

This article, along with the achievements and problems of agricultural producers, shows that the development of mathematical tools suitable for forecasting the cost of crop cultivation is the most important. The cost price is formalized with algebraic equations that are convenient for calculating the cost price of any of the mentioned crops for an arbitrary period in the future. An equation is calculated for each region for each cultivated crop that is easy to remember without remembering the numbers of a particular cost. In order to obtain a specific number, the number by one greater than the last two digits of the year for which the cost is to be calculated must be set instead of $\mathrm{X}$ in the corresponding equation in table 1. For example, for the 2030 projection $X=31$. Crops marked in colour in the table are not profitable to grow in the indicated region and those absent in it are unprofitable.

Representation of crop production costs in the form of equations, in our view, is the digitization of the agricultural industry. The land cadastre will determine the target direction for the use of the plots of land and territorial zones, and the cost-of-cultivation equations will indicate the efficient use of these lands.

Joint use of the information contained in the State Land Cadastre and the equations for forecasting the cost of cultivation of specific crops is the amount of knowledge necessary for the implementation of state land management in the country. A set of quantitative and qualitative indicators characterizing the state of the population's habitat and including cartographic (visual, statistical and textual) information, supplemented by water, forest, subsoil, mountain, urban planning, railway and other industry cadastres (which have been developed and used by Russians in the management decision-making process) is sufficient information for the effective management not only of immovable natural resources of Russia, but also what benefits can be derived from them. The equations for forecasting the cost of land use in the grocery direction can help to compile an original product inventory of the quality of lands and territories of Russia.

Such values can be useful for farmers who want to hold land under a lease, investors, buyers who purchase grain directly from fields by self-pickup.

The equations are calculated not only of the lower but also of the upper cost limit, reaching which for at least a few crops makes the farm bankrupt. 
Table 1. Economic and mathematical model of crop production projected cost by districts Rostov region (lower limit). To calculate the forecast for $2020, X=21, \ldots 2023-X=24$ should be substituted.

\begin{tabular}{|c|c|c|c|c|c|c|}
\hline \multirow{2}{*}{ Zones, districts } & \multirow[t]{2}{*}{ Crops } & \multicolumn{5}{|c|}{ Lower cost limit, rub. / hundredweight } \\
\hline & & Equation & 2020 & 2021 & 2022 & 2023 \\
\hline \begin{tabular}{|l|} 
I. The North \\
Western zone
\end{tabular} & Winter grains & $-0.5 x^{2}+13.6 x+69$ & 134.10 & 126.20 & 117.30 & 107.40 \\
\hline \multirow{2}{*}{$\begin{array}{l}\text { Sholokhovsky } \\
\text { district }\end{array}$} & Spring grains & $0.98 x^{2}+26.3 x+86.8$ & 206.94 & 191.10 & 173.30 & 153.54 \\
\hline & Sunflower & $-1.43 x^{2}+47.96 x+12$ & 492.17 & 478.64 & 462.25 & 443.00 \\
\hline \multirow[t]{3}{*}{$\begin{array}{l}\text { Verkhnedonskoy } \\
\text { district } \\
\end{array}$} & Winter grains & $-0.3 x^{2}+17.1 x+66.2$ & 293.00 & 297.20 & 300.80 & 303.80 \\
\hline & Spring grains & $1.46 x^{2}+32.68 x+86$ & 128.62 & 98.52 & 65.50 & 29.56 \\
\hline & Sunflower & $0.97 x^{2}+36.85 x+165$ & 512.46 & 507.69 & 500.98 & 492.33 \\
\hline \multirow{3}{*}{$\begin{array}{l}\text { Bokovsky } \\
\text { district }\end{array}$} & Winter grains & $0.81 x^{2}+2.4 x+112$ & 519.61 & 556.84 & 595.69 & 636.16 \\
\hline & Spring grains & $-0.06 x^{2}+9.39 x+160$ & 330.33 & 337.14 & 343.83 & 350.40 \\
\hline & Sunflower & $0.1 x^{2}+21.99 x+187$ & 605.26 & 622.95 & 640.44 & 657.73 \\
\hline \multirow[t]{2}{*}{$\begin{array}{l}\text { Millerovsky } \\
\text { district }\end{array}$} & Winter grains & $0.25 x^{2}+13.7 x+75.6$ & 473.55 & 498.00 & 522.95 & 548.40 \\
\hline & Sunflower & $1.62 x^{2}+42.7 x+129.9$ & 312.22 & 285.26 & 255.06 & 221.62 \\
\hline \multirow[t]{3}{*}{\begin{tabular}{|l} 
Kasharsky \\
district
\end{tabular}} & Winter grains & $0.36 x^{2}+11.6 x+80.3$ & 165.14 & 161.26 & 156.66 & 151.34 \\
\hline & Spring grains & $1.25 x^{2}+28.62 x+68.17$ & 117.94 & 92.81 & 65.18 & 35.05 \\
\hline & Sunflower & $0.7 x^{2}+25.98 x+117.5$ & 354.38 & 350.26 & 344.74 & 337.82 \\
\hline \multirow[t]{3}{*}{\begin{tabular}{|l|} 
Tarasovsky \\
district
\end{tabular}} & Winter grains & $1.09 x^{2}+0.63 x+131$ & 624.92 & 672.42 & 722.10 & 773.96 \\
\hline & Spring grains & $0.89 x^{2}+22.41 x+113.6$ & 191.72 & 175.86 & 158.22 & 138.80 \\
\hline & Sunflower & $-1.95 x^{2}+44 x+155.8$ & 219.85 & 180.00 & 136.25 & 88.60 \\
\hline \multirow[t]{3}{*}{\begin{tabular}{|l}
$\begin{array}{l}\text { Kamensky } \\
\text { district }\end{array}$ \\
\end{tabular}} & Winter grains & $0.5 x^{2}+12 x+92.3$ & 564.80 & 598.30 & 632.80 & 668.30 \\
\hline & Spring grains & $1.2 x^{2}+29.55 x+82.96$ & 174.31 & 152.26 & 127.81 & 100.96 \\
\hline & Sunflower & $0.58 x^{2}+24 x+188.44$ & 948.22 & 997.16 & 1047.26 & 1098.52 \\
\hline $\begin{array}{l}\text { II. The North } \\
\text { Eastern zone }\end{array}$ & Winter grains & $0.91 x^{2}-4.72 x+133.4$ & 435.59 & 470.00 & 506.23 & 544.28 \\
\hline \multirow[t]{2}{*}{$\begin{array}{l}\text { Belokalitvinsky } \\
\text { district }\end{array}$} & Spring grains & $-0.76 x^{2}+20.2 x+102$ & 191.04 & 178.56 & 164.56 & 149.04 \\
\hline & Sunflower & $0.71 x^{2}+32.31 x+175$ & 540.25 & 542.03 & 542.39 & 541.33 \\
\hline \multirow[t]{3}{*}{\begin{tabular}{|l|} 
Tatsinsky \\
district
\end{tabular}} & Winter grains & $2.98 x^{2}-35.8 x+43.8$ & 606.18 & 698.52 & 796.82 & 901.08 \\
\hline & Spring grains & $-0.67 x^{2}+36.2 x+52.39$ & 517.12 & 524.51 & 530.56 & 535.27 \\
\hline & Sunflower & $0.18 x^{2}+36.58 x+127.3$ & 974.86 & 1019.18 & 1063.86 & 1108.0 \\
\hline \multirow[t]{3}{*}{$\begin{array}{l}\text { Morozovsky } \\
\text { district }\end{array}$} & Winter grains & $1.69 x^{2}-9.5 x+25.85$ & 571.64 & 634.81 & 701.36 & 771.29 \\
\hline & Spring grains & $0.96 x^{2}+22.47 x+86$ & 134.86 & 116.05 & 95.32 & 72.67 \\
\hline & Sunflower & $0.85 x^{2}+30.1 x+183$ & 1190.19 & 1256.84 & 1325.19 & 1395.24 \\
\hline \multirow[t]{3}{*}{$\begin{array}{l}\text { Milyutinsky } \\
\text { district }\end{array}$} & Winter grains & $1.9 x^{2}-11.5 x+120.2$ & 716.6 & 786.8 & 860.8 & 938.6 \\
\hline & Spring grains & $-0.91 x^{2}+25.6 x+58.83$ & 195.13 & 181.59 & 166.24 & 149.07 \\
\hline & Sunflower & $1.33 \mathrm{x}^{2}+42.8 \mathrm{x}+92.9$ & 405.21 & 390.82 & 373.77 & 354.06 \\
\hline \multirow[t]{3}{*}{ Sovetsky district } & Winter grains & $0.18 x^{2}+5.99 x+93.5$ & 139.95 & 138.20 & 136.09 & 133.62 \\
\hline & Spring grains & $0.43 x^{2}+15.83 x+129$ & 272.01 & 269.35 & 265.83 & 261.45 \\
\hline & Sunflower & $3.11 x^{2}-55.88 x+248$ & 446.03 & 523.88 & 607.95 & 698.24 \\
\hline
\end{tabular}


Table 2. Economic and mathematical model of crop production projected cost by districts Rostov region (upper limit), rub./hundredweight. To calculate the forecast for $2020, X=21, \ldots 2023-X=24$ should be substituted.

\begin{tabular}{|c|c|c|c|c|}
\hline Areas, areas & Crops & Upper cost limit equation & 2022 & 2023 \\
\hline $\begin{array}{l}\text { I. The North Western } \\
\text { zone }\end{array}$ & Winter grains & $-0.37 x^{2}+15.9 x+60.6$ & 230.57 & 229.08 \\
\hline \multirow[t]{2}{*}{ Sholokhovsky district } & Spring grains & $-0.53 x^{2}+29.47 x+71.85$ & 469.29 & 473.85 \\
\hline & Sunflower & $-0.075 x^{2}+52.84 x+86.27$ & 1261.92 & 1311.23 \\
\hline \multirow[t]{3}{*}{ Verkhnedonskoy district } & Winter grains & $0.47 x^{2}+20 x+49.0$ & 757.63 & 799.72 \\
\hline & Spring grains & $-1.13 x^{2}+35.08 x+75.52$ & 284.59 & 266.56 \\
\hline & Sunflower & $0.072 \mathrm{x}^{2}+43.62+134.43$ & 216.14 & 219.52 \\
\hline \multirow[t]{3}{*}{ Bokovsky district } & Winter grains & $2.1 x^{2}+5.1 x+90.0$ & 1318.20 & 1422.00 \\
\hline & Spring grains & $0.283 x^{2}+14.27 x+141.77$ & 619.69 & 647.26 \\
\hline & Sunflower & $0.97 \mathrm{x}^{2}+28.8 \mathrm{x}+156.02$ & 1331.55 & 1405.94 \\
\hline \multirow[t]{3}{*}{ Chertkovsky district } & Winter grains & $-0.27 x^{2}+26.4 x+47.4$ & 511.77 & 525.48 \\
\hline & Spring grains & $-1.116 x^{2}+32.495 x+49.3$ & 206.32 & 186.36 \\
\hline & Sunflower & $-0.49 x^{2}+45.21 x+117.75$ & 898.37 & 920.55 \\
\hline \multirow[t]{3}{*}{\begin{tabular}{|l|} 
Millerovsky district \\
\end{tabular}} & Winter grains & $1.76 x^{2}+14.8 x+55.3$ & 1326.74 & 1424.26 \\
\hline & Spring grains & $-1.77 x^{2}+43.33 x+48.19$ & 108.45 & 68.59 \\
\hline & Sunflower & $-0.956 x^{2}+47.89 x+107.6$ & 703.35 & 706.30 \\
\hline \multirow[t]{3}{*}{\begin{tabular}{|l|} 
Kasharsky district \\
\end{tabular}} & Winter grains & $-0.12 x^{2}+14.1 x+70.3$ & 331.12 & 339.58 \\
\hline & Spring grains & $-0.934 x^{2}+30.92 x+58$ & 275.07 & 262.10 \\
\hline & Sunflower & $0.006 x^{2}+30.56 x+96.25$ & 802.30 & 833.15 \\
\hline \multirow[t]{3}{*}{ Tarasovsky district } & Winter grains & $2.66 x^{2}+3.69 x+104.5$ & 1596.51 & 1725.22 \\
\hline & Spring grains & $-0.61 x^{2}+26.32 x+99.16$ & 381.83 & 379.48 \\
\hline & Sunflower & $-1.54 x^{2}+48.16 x+139.27$ & 432.29 & 408.07 \\
\hline \multirow[t]{3}{*}{ Kamensky district } & Winter grains & $2.24 x^{2}+12.8 x+70.4$ & 1549.76 & 1667.84 \\
\hline & Spring grains & $-0.8 x^{2}+32.78 x+69.01$ & 399.75 & 394.93 \\
\hline & Sunflower & $2.93 x^{2}+28.79 x+148.5$ & 2360.64 & 2527.14 \\
\hline \multirow[t]{3}{*}{ Krasnosulinsky district } & Winter grains & $1.46 x^{2}+18.3 x+55.6$ & 1248.84 & 1335.76 \\
\hline & Spring grains & $-1.09 x^{2}+32.49 x+71.74$ & 242.40 & 223.66 \\
\hline & Sunflower & $-1.68 x^{2}+45.48 x+138.74$ & 296.06 & 262.58 \\
\hline $\begin{array}{l}\begin{array}{l}\text { II. The North Eastern } \\
\text { zone }\end{array} \\
\end{array}$ & Winter grains & $1.81 x^{2}-9.18 x+113.83$ & 860.18 & 936.07 \\
\hline \multirow[t]{2}{*}{\begin{tabular}{|l|} 
Belokalitvinsky district \\
\end{tabular}} & Spring grains & $-0.5 x^{2}+24.13 x+87.41$ & 377.90 & 378.53 \\
\hline & Sunflower & $0.3 \mathrm{x}^{2}+39.35 \mathrm{x}+143.34$ & 1207.09 & 1260.54 \\
\hline \multirow[t]{3}{*}{\begin{tabular}{|l|} 
Tatsinsky district \\
\end{tabular}} & Winter grains & $5.58 x^{2}-75.7 x+190.8$ & 1401.62 & 1588.08 \\
\hline & Spring grains & $-1.31 x^{2}+38.46 x+41.9$ & 233.49 & 210.38 \\
\hline & Sunflower & $3.37 x^{2}+36.08 x+93$ & 2705.57 & 2900.04 \\
\hline \multirow[t]{3}{*}{ Morozovsky district } & Winter grains & $7.73 x^{2}-22.8 x+122$ & 3686.77 & 4027.28 \\
\hline & Spring grains & $-0.73 x^{2}+25.54 x+74.89$ & 276.14 & 267.37 \\
\hline & Sunflower & $4.4 x^{2}+30.5 x+142.2$ & 3171.30 & 3408.60 \\
\hline \multirow[t]{3}{*}{ Milyutinsky district } & Winter grains & $8.04 x^{2}-33.35 x+125.72$ & 3611.83 & 3956.36 \\
\hline & Spring grains & $-0.917 x^{2}+26.49 x+51.76$ & 175.94 & 159.33 \\
\hline & Sunflower & $-0.18 x^{2}+47.03 x+67.86$ & 1054.33 & 1092.90 \\
\hline \multirow[t]{3}{*}{\begin{tabular}{|l} 
Sovetsky district \\
\end{tabular}} & Winter grains & $-0.1 x^{2}+8.24 x+86.33$ & 222.95 & 226.49 \\
\hline & Spring grains & $-0.176 x^{2}+20.53 x+113.2$ & 492.29 & 504.54 \\
\hline & Sunflower & $12.03 x^{2}-50.67 x+241.46$ & 5439.92 & 5954.66 \\
\hline
\end{tabular}

\section{Consolation}

The forecasted cost price makes it possible to determine sufficiently the benefits of crop areas in predetermined combinations, to identify inefficient areas (for example, composting pits previously used for planting wintertime feeds for cattle). Cost forecasts will help farmers to select the most appropriate seeds, based on knowledge of the region's lands, to ensure high yields. The introduction of the digital economic system of the agro-industrial complex has already started in the Southern Region. Captive banks issue loans to farmers 
for a socially responsible project - digitization of agriculture. Large farms are becoming digitalization leaders, followed by medium and small businesses.

Costs affect the decision-making on what to produce and what to buy ready-made, whether to deal with a buyer or not. If the cost of growing a particular crop exceeds the upper limit (Table 1), farm management needs to be strengthened (if the reason for the climatic nature is drought, flooding is not recorded).

Since the cost of grain production in Central Europe is many times higher than that of the Rostov region, the strategy of agricultural producers should be to export unclaimed grain to Russia.

Even in a small territory of the Rostov region, zones of high cost and favourable cultivation of specific crops in certain areas of the region have been identified, the scatter of the prime costs of the same crop in different regions of the same natural and climatic zone, as well as in different zones, has been determined.

Export promotion, development of various forms of trade transactions in domestic and foreign networks, advertising, organization of individual orders, and creation of a network of firm shops are required.

The extension of the working season on agricultural production through the transformation of the crop into ready-to-eat foodstuffs and sales not only through trade networks, but also on their own behalf, will allow, without focusing on cost, to earn money, providing households with financial independence from investments in the future harvest.

Cost prediction equations can form the basis of cadastre of the quality of Russia's lands and territories in ensuring the safety of Russians' livelihood.

State property not covered by cadastres or not assigned to State enterprises and institutions constitutes the State treasury of the Russian Federation - the weakest link in human society in need of digitization, cybernetics, systematization, management by objectives.

The problem of digitization of the agricultural production sector is being updated in the launched implementation of the Chinese railway initiative «One Belt, One Way», since a huge number of farmland on the territory of the Russian Federation will be transferred to the railway transport industry, to the international use zone, as well as in the form of lease. In the process of land alienation, as an argument for minimizing the loss of arable land, it is possible to use the equations proposed in this article for predicting the cost of cultivation of crops and the author's algorithms for compiling them according to the method of D.V.

Frolov.

\section{References}

1. P. Adämmer, M.T. Bohl, Journal of Futures Markets, 38 (5), 549-562 (2018)

2. M. Svanidze, L. Götz, Global Food Security, 21, 60-68 (2019)

3. J. Baffes, V. Kshirsagar, D. Mitchell, The World Bank Economic Review, 8, 1-25 (2017)

4. M. Belyaeva, R. Bokusheva, A statistical evidence from a panel approach Climatic Change, 149 (2), 205-217 (2018)

5. L.V. Borisova, T.P. Kuzminskaia, A.A. Alukhanian, T.V. Zhukova, et al., Building effective management solutions in uncertain environments: modern experience, perspectives, innovation, (PE S.V. Bespamyatnov, Rostov-on-Don, Monograph, 86-97 (2018)

6. A. Ebata, P.A. Velasco Pacheco, S. Cramon-Taubadel, Agricultural Economics (United Kingdom), 48, (4), 459-467 (2017)

7. P.L. Fackler, B.K. Goodwin, Elsevier, Amsterdam, 971-1024 (2001) 
8. A. Belozertsev, L. Rutten, F. Hollinger, FAO/World Bank, Rome (2011)

9. T. Fellmann, S. Hélaine, O. Nekhay, Food Security, 6, (5), 727-742 (2014)

10. T. Glauben, S. Prehn, T. Dannemann, B. Brümmer, Summary of IAMO 20 policy (2014)

11. L. Götz, I. Djuric, O. Nivievskyi, Journal of Agricultural Economics, 67 (3), 741-763 (2016)

12. L. Götz, TJ. Jaghdani, Russia's agricultural import substitution policy: price volatility effects on the pork supply chain (57th GEWISOLA Conference, Munich, Germany, 2017)

13. L. Götz, U. Koester, T. Glauben, R. Bulavin, The Rouble Crisis and Russian Wheat Export Controls, Intereconomics, 50, (4), 227-233 (2015)

14. L. Götz, T. Glauben, B. Brümmer, Food Policy, 38, (1), 214-226 (2013)

15. C. Kouyaté, S. Cramon-Taubadel, Journal of Agricultural Economics, 67, (2), 255-271 (2016)

16. J.B. Lewis, D.A. Linzer, Political Analysis, 13, (4), 345-364 (2005)

17. W.M. Liefert, Agricultural Economics, 40, (1), 15-28 (2009)

18. E. Lioubimtseva, G.M. Henebry, Frontiers of Earth Science, 6, (2), 157-166 (2012)

19. A.M. McKenzie, M.T. Holt, Applied Economics, 34, (12), 1519-1532 (2002)

20. M. Peri, L. Baldi, D. Vandone, Applied Economics Letters, 20, (4), 397-403 (2013)

21. N. Rada, W. Liefert, O. Liefert, Journal of Agricultural Economics, 10(11), 38-45 (2020)

22. F. Schierhorn, D. Müller, A.V. Prishchepov, M. Faramarzi, A. Balmann, Global Food Security, 3, (3-4), 133-141 (2014)

23. E.C. Stephens, E. Mabaya, S.V. Cramon-Taubadel, C.B. Barrett, Oxford Bulletin of Economics and Statistics, 74, (3), 453-469 (2012)

24. J. Swinnen, S. Burkitbayeva, F. Schierhorn, A.V. Prishchepov, D. Müller, Global Food Security, 14, 38-53 (2017)

25. W. Zant, World Bank Economic Review, 32, (2), 334-356 (2018) 